\title{
GREENHOUSE HEATING AND VENTILATION CONTROL SYSTEM
}

\author{
Shaymaa Abed Elfattah,* Mubarak M. Mostafa,* \\ Mahmoud A. Elnono * and Ahmed M. Kassem**
}

\begin{abstract}
This research aims to study the effect of using the heating and ventilation system on the production and quality of tomato crop in winter season. Two different poly-greenhouse models were constructed at Al-Zahwiyyin, Egypt $\left(\phi=30^{\circ} 15^{\prime} \mathrm{N}\right)$. It was equipped with heating and ventilation control system (treatment) and the other was a traditional greenhouse (control). Results of the experimental work show that the specific approach of heating and mechanical ventilation for tomato crop production enhances the rate of growth and increasing the fresh tomato yield by $57.69 \%$ comparing with control greenhouse. The quality of tomato crop of the treatment greenhouse can be noticed through the firmness and toughness value comparing with the control one. They were greater by $85 \%$ and $62.5 \%$, respectively.
\end{abstract}

Keywords: Greenhouses, Heating system, Ventilation, Relative humidity

\section{INTRODUCTION}

$\mathrm{P}$ olyethylene greenhouses used in Egypt on an increasingly large scale for early production of warm-season vegetable, fruit and flowers. It is a good application of solar energy collection for space heating and plant production. Moreover, its productivity per unit area is greater than the field production, and its product quality is always the highest. However, in winter, supplementary heating is necessary at night and during periods of gray sky to maintain the required plant temperature. Also, proper manipulation of the moisture in the greenhouse air by use of heat and ventilation is necessary to reduce or prevent fungous diseases that cause great losses and cannot easily controlled with fungicides.

Generally, Climate control is of great importance for greenhouse production in order to achieve high yield and good quality crops that meet the demands of consumers, as well as for economical production.

\footnotetext{
*Agric. Eng. Dept., Fac. of Agric., Ain Shams Univ. **Agric. Eng. Research Institute, ARC.
} 
Temperature and relative humidity $(\mathrm{RH})$ are two basic climatic parameters usually controlled by heating and ventilation equipment. It is more difficult to control RH than temperature because relative humidity not only relies on air exchange from the infiltration and ventilation, but also related to evaporation from growing media and transpiration of the plants. (Gao 2012)

Therefore, the present research is aimed to develop, construct, and test an experimental greenhouse that will be equipped with heating and ventilation control system to maintain optimum growing environment for tomato growth during winter season through the following specific objective:-

1- Connecting the greenhouse to an adequate heating system.

2- Supplying the designed system with environmental instruments to control the interior climate for plant growth under environmentally controlled high-yield conditions as well as offering an opportunity to reduce the electrical energy consumption.

3- Investigating the effect of adequate mechanical ventilation to adjust the relative humidity of air inside the constructed greenhouse.

4- Comparing the productivity of the designed system with a traditional greenhouse that has the same shape, dimensions, cover, and orientation with natural ventilation.

\section{MATERIAL AND METHODS}

1- Description of the greenhouses:-

Two identical gable-even-span greenhouses were designed, constructed and installed on the roof of a house at Al-Zahwiyyin village, Al-Qaliobia Governorate, Egypt $\left(\phi=30^{\circ} 15^{\prime} \mathrm{N}\right)$. The construction was made of steel angle (1" x 1" x 3/16"). Each greenhouse was $4.0 \mathrm{~m}$ long and $3 \mathrm{~m}$ wide with a single gable at maximum height of $1 \mathrm{~m}$, whilst the height of sidewall was $2 \mathrm{~m}$. The greenhouse frame was covered using $0.1 \mathrm{~mm}$ thickness polyethylene sheet. It was oriented in north-south direction, one longitudinal side facing south and other facing north (Fig.1), and the roof was sloped at an angle $26.6^{\circ}$.

The first greenhouse was used to study and test the effect of heating the interior climate and mechanical ventilation on the growth and production 
of tomato crop. It was connected to an insulated storage tank of pure water, which was supplied with an electrical heater, through heat exchanger inside the greenhouse and small size pump to circulate the hot water in closed loop in order to transfer extra thermal energy to the interior climate for accelerating the growth of plants during winter season. Storage tank

A galvanized steel tank, (100 liters capacity) filled with 60 liter of water was used. It has cylindrical shape, diameter of $0.46 \mathrm{~m}$ and height of 0.62 $\mathrm{m}$. It was insulated using a glass wool insulation of 3 inches $(76.200 \mathrm{~mm})$ thickness to reduce the thermal losses to the ambient. It was provided with an electrical heater (type R-T-M water heater- made in Italy) and a thermostat (single-pole $40-80{ }^{\circ} \mathrm{C}$ ) to adjust the water temperature at about $60{ }^{\circ} \mathrm{C}$. It had an outlet galvanized tube $(3 / 4 "$ diameter $)(19.05 \mathrm{~mm})$ at the bottom which was connected to the intake-mouse of the pump, and input tube (3/4" diameter) at the top which was connected to the external outlet connection of the heat exchanger. The tubes were also insulated by 3 inches thickness glass wool.

Heat exchanger

Heat exchanger was made of galvanized pipes (3/4" diameter) and placed inside the greenhouse at $20 \mathrm{~cm}$ above the ground; It was used to transfer the heat from the working fluid (hot pure water) to the interior climate of the greenhouse to maintaine the required plant temperature. Two thermocouples ( $\mathrm{k}$ type) were used to measure the inlet and outlet temperatures of heat exchanger.

$\underline{\text { Pump }}$

An electrical rotary pump ( $0.5 \mathrm{HP}$, model QP-60, 21 1/min capacity, made in China) was used to circulate the working fluid.

Ventilation fan

A $40 \mathrm{~cm}$ diameter ventilation fan (FAD104 model, $200 \mathrm{~m}^{3} / \mathrm{h}$ capacity, $1400 \mathrm{rpm}, 145 \mathrm{~W}$ power) was used to exchange the air inside the greenhouse. The fan placed on the opposite side of the intake window (50 $\mathrm{X} 50 \mathrm{~cm}$ ) of air (Ventilation shutter).

2- Instrumentation

a- Thermocouples (K-type) and a digital thermometer (DM6801A, made in China, $-50{ }^{\circ} \mathrm{C}$ to $1300{ }^{\circ} \mathrm{C}$ range, $\pm 0.3 \%$ accuracy) were used to 
measure the following temperatures: the inlet and outlet temperatures of the heat exchanger, air in and outside the greenhouse.

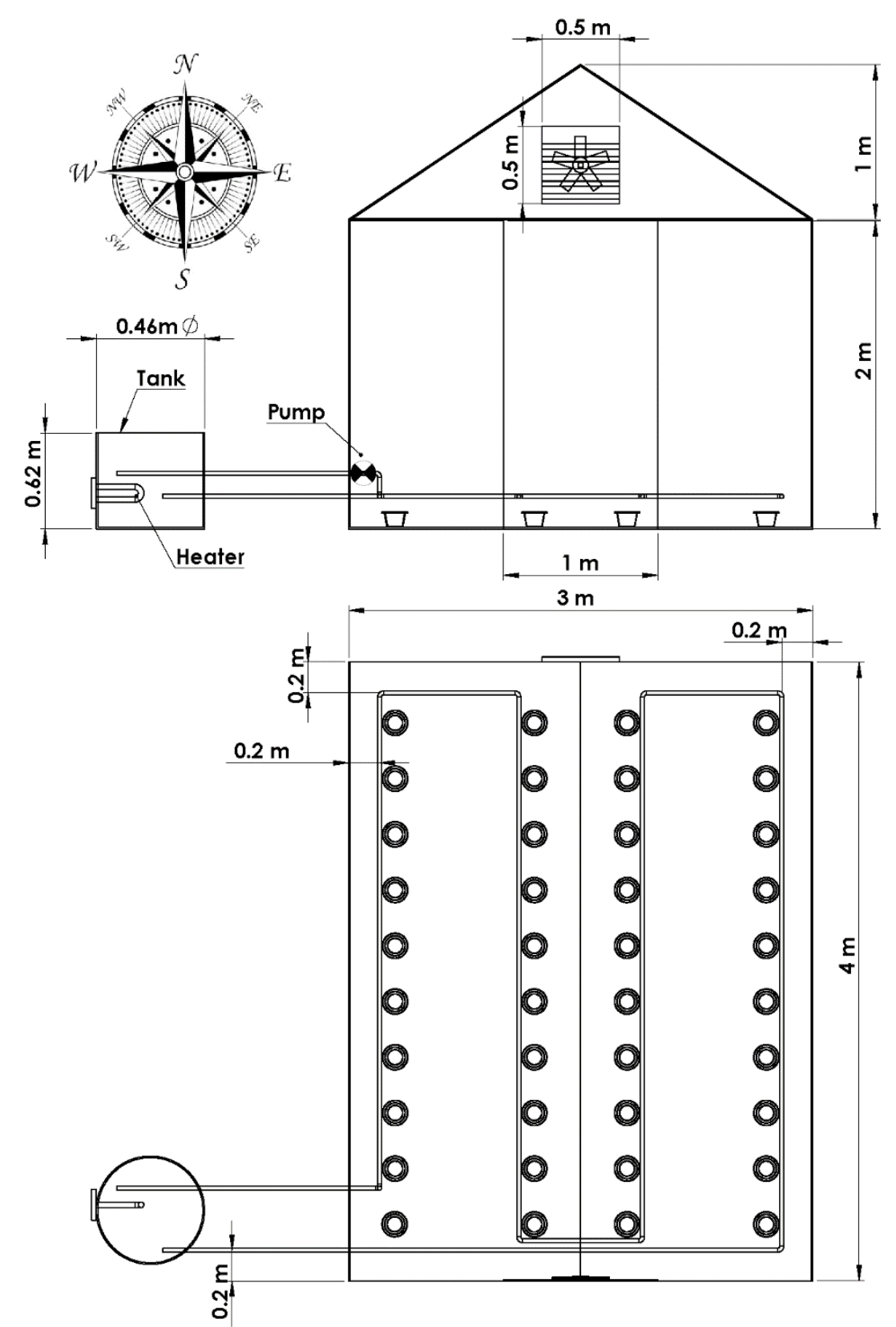

Fig.1: Schematic diagram showing the basic dimensions and component of the constructed greenhouse 
b- Two electrical thermostats were used. The first one $\left(10-60{ }^{\circ} \mathrm{C}\right.$ range $)$ was used to control the water pump operation. When the inside temperature of the greenhouse air is lower than $20^{\circ} \mathrm{C}$, the thermostat operates the pump until the air temperature reaches the desired plant temperature. The other one is to operate the exhaust fan if the greenhouse air temperature exceeds $28^{\circ} \mathrm{C}$.

c- Digital temperature and humidity meter (HTC2, 20-50 ${ }^{\circ} \mathrm{C}$ temperature range, $10 \%-95 \%$ RH range, made in china) was used as a humiditysensing device to measure the air humidity of the greenhouse and a humidistat $(35 \%-95 \% \mathrm{RH}$ range $\pm 3.0 \%)$ was used to operate the exhaust fan of the ventilation system when the relative humidity exceeds $75 \%$. It was necessary to use such device because on cold days of winter, especially at night, the ventilation fan would not be operated, it was adjusted to operate on the temperature rise (greater than $28{ }^{\circ} \mathrm{C}$ ), and the RH could be increased (more than 75\%) which may initiate some serious disease problems.

3- Heat losses from the greenhouse

a- Heat flow through the polyethylene

Heat flow through the greenhouse covering materials (walls and roof) during the heating season is represented the greatest losses with respect to the other energy losses from the greenhouse. It is generally related the temperature difference between the inside and outside temperature by the overall heat transfer coefficient as following

$$
Q_{c}=U \times A \times\left(T_{i}-T_{o}\right) \quad \text { (Ibrahim, } 2000 \text { and Abdel-Lattif, 1993) }
$$

Where

$\mathrm{Q}_{\mathrm{c}} \quad$ : Heat flow, $\mathrm{J} / \mathrm{s}$;

$\mathrm{U} \quad$ : Overall heat transfer coefficient, $\mathrm{W} /\left(\mathrm{m}^{2} .{ }^{\circ} \mathrm{C}\right)$;

A : $\quad$ Area of greenhouse wall and roof, $\mathrm{m} 2$;

$\mathrm{T}_{\mathrm{i}} \quad$ : Interior ambient air temperature, ${ }^{\circ} \mathrm{C}$;

$\mathrm{T}_{\mathrm{o}} \quad$ : Exterior ambient air temperature, ${ }^{\circ} \mathrm{C}$. 
b- Energy loss via ventilation

Heat loss via ventilation $\left(\mathrm{Q}_{\mathrm{v}}\right)$ is approximated as follows (Ibrahim, 2000)

$$
\mathrm{Q}_{\mathrm{v}}=\mathrm{Q}_{\mathrm{sv}}+\mathrm{Q}_{\mathrm{lv}}
$$

Where

$\mathrm{Q}_{\mathrm{sv}}$ is the sensible heat losses via ventilation;

$\mathrm{Q}_{\mathrm{lv}}$ is latent heat losses via ventilation;

$\mathrm{Q}_{\mathrm{sv}}=\dot{m} \times c p \times\left(T_{\text {in }}-T_{o}\right), \mathrm{J} / \mathrm{s}$ (Abdel-Lattif, 1993).

$Q_{l v}=E \times F \times Q_{i}=E \times F \times \tau I A_{f}$

Where

$\tau \quad$ Transmittance of greenhouse covering (assumed 88\%);

I Total solar radiation outside the greenhouse on horizontal surface $\left(\mathrm{W} / \mathrm{m}^{2}\right)$, it was obtained from the weather station of the arid land and agricultural research and services center Faculty of Agriculture,Ain Shams University. ;

$A_{f} \quad$ Floor area of the greenhouse, $\left(\mathrm{m}^{2}\right)$;

$T_{i n}, T_{o}$ Inside and outside air temperature of greenhouse;

$\dot{m} \quad$ Mass flow rate of air $\mathrm{kg} / \mathrm{s}=\mathrm{Mx} \rho / 3600$, (Abdel-

$$
\text { Lattif, 1993) ; }
$$

Where

$\mathrm{M}=$ greenhouse volume $\mathrm{x}$ air exchange rate per hour, $\left(\mathrm{m}^{3} / \mathrm{h}\right)$; $\rho=\operatorname{air} \operatorname{density}\left(=1.2 \mathrm{~kg} / \mathrm{m}^{3}\right)$;

$\mathrm{C}_{\mathrm{p}}=$ Air specific heat $1007 \mathrm{~J} / \mathrm{kg} .{ }^{\circ} \mathrm{C}$;

$\mathrm{E}=$ Floor use factor - ratio of ground covered by plants to total ground area, (assumed 0.4 );

$\mathrm{F}=$ Evapotranspiration to internal solar radiation (assumed $0.5)$.

c- Total losses

$$
\mathrm{Q}_{\text {loss }}=\mathrm{Q}_{\mathrm{c}}+\mathrm{Q}_{\mathrm{v}}
$$

4- Heating system

Heating system delivers heat energy from boiler to the air of the greenhouse by circulating hot water through piping system of the heat exchanger, and the rate of heat transfer may be approximated by the equation 


$$
Q_{h l}=\dot{m}_{w} \times C_{p_{w}} \times\left(T_{\text {exi }}-T_{\text {exo }}\right)
$$

Where

$Q_{h l} \quad:$ the rate of heat transfer, $\mathrm{J} / \mathrm{s}$;

$\dot{m}_{w} \quad$ : Water mass flow rate, $\quad \mathrm{kg} / \mathrm{s}$;

$C_{p_{w}}:$ Water specific heat, $\quad\left(4190 \mathrm{~J} / \mathrm{kg} .{ }^{\circ} \mathrm{C}\right)$;

$T_{\text {exi }} \quad$ : Inlet temperature of the heat exchanger, ${ }^{\circ} \mathrm{C}$;

$T_{\text {exo }} \quad$ : Outlet temperature of the heat exchanger, ${ }^{\circ} \mathrm{C}$.

5- Mechanical ventilation

a- Determining ventilation volume rate

The ventilation volume rate may be calculated by the following equation Air volume flow rate $\left(\mathrm{m}^{3} / \mathrm{h}\right)=\mathrm{V}_{\text {gh }} \times \mathrm{AR}$

Where

Vgr : Greenhouse volume, $\mathrm{m}^{3}$;

AR : Air exchange rate per hour $1 / \mathrm{h}$

In Winter $\mathrm{AR}=2 \quad 1 / \mathrm{h} \quad$ (Buffington et al., 2002).

b- Size of the intake vent

The following equation is used to determine the area of the air inlet

Size of the intake vent $=\frac{\text { Air volumetric flow rate }\left(\mathrm{m}^{3} / \mathrm{h}\right)}{\text { Maximum air speed allowed }(\mathrm{m} / \mathrm{h})}$

Since air speed influences many factors that affect plant growth, such as transpiration, evaporation, leaf temperature, and carbon dioxide availability, the maximum air speed allowed through the vent was used to be $1.27 \mathrm{~m} / \mathrm{s}$ (Abdel-Lattif, 1993 and Aldrish and Bartok, 1994).

6- Natural ventilation

Natural ventilation depends upon the ventilation opening area's and positions, to achieve the optimum air exchange in the greenhouse, the lateral wall opening and roof holes in the range (15-30)\% of the floor area of the greenhouse (Ibrahim, 2000).

7- Firmness value:-

The mechanical damage of tomatoes usually occurs as a result of careless handling at mechanical harvest, package, and transport (Li et al., 2013), therefore firmness values of tomatoes are the most important internal quality to retail marketing or using at home (Sirisomboon et al.,2012). It is defined as the ability of fruit to retain its original shape when exposed to 
external force and usually it is described by the fruit's force-deformation behavior. (Rajabipour, 1995 and BATU, 1998). Jackman et al. (1990) indicated that firmness of tomatoes has commonly been measured by flatplate compression or by puncture of whole fruit and defined as either the force at failure or the ratio of force to deformation at failure.

In this study a number of tests are conducted under certain puncture force by specific point on the tomato fruit and the resulting force deformation curve is obtained using Tinius Olsen Benchtop Materials Testing machines with a plunger diameter $(6.05 \mathrm{~mm})$, then the firmness is determined as the following (Sirisomboon et al.,2012)

Average firmness $=\frac{\Delta F_{r}}{\Delta D_{r}}, \quad\left(\frac{N}{m m}\right)$

Where

$\Delta F_{r}$ Is the rapture force , $(\mathrm{N})$;

$\Delta D_{r}$ Is deformation at the rapture point, $\quad(\mathrm{mm})$.

\section{8- Toughness :-}

Toughness is defined as the area under the complete force-deformation curve from the origin to the rapture point $(\mathrm{N} / \mathrm{mm})$

Toughness $=\frac{\mathbf{1}}{\mathbf{2}} \times F_{r} \times D_{r} \quad$ (Shafiee et al., 2008)

Planting and harvesting time

Each greenhouse was equipped by 40 pots $(30 \mathrm{~cm}$ high and $25 \mathrm{~cm}$ diameter).

a- Planting time $1 / 1 / 2012$

b- Flowering First date of the treatment greenhouse was 25/1/2012 and the control greenhouse was 7/2/2012.

c- Vegetating date of the treatment greenhouse was $6 / 2 / 2012$ and the control greenhouse was 23/2/2012.

d- The first date of picked tomatoes of the treatment greenhouse was $14 / 3 / 2012$ and the control greenhouse was 4/4/2012. 


\section{RESULTS AND DISCUSSION}

1- Hourly variation of temperatures:

Fig. (2) illustrates the average hourly temperatures variation of the ambient and inside the treatment and control greenhouses. The results show that the temperatures of the air gradually increased with the time, which peaked at about 2:00 pm, then reduced towards the evening.

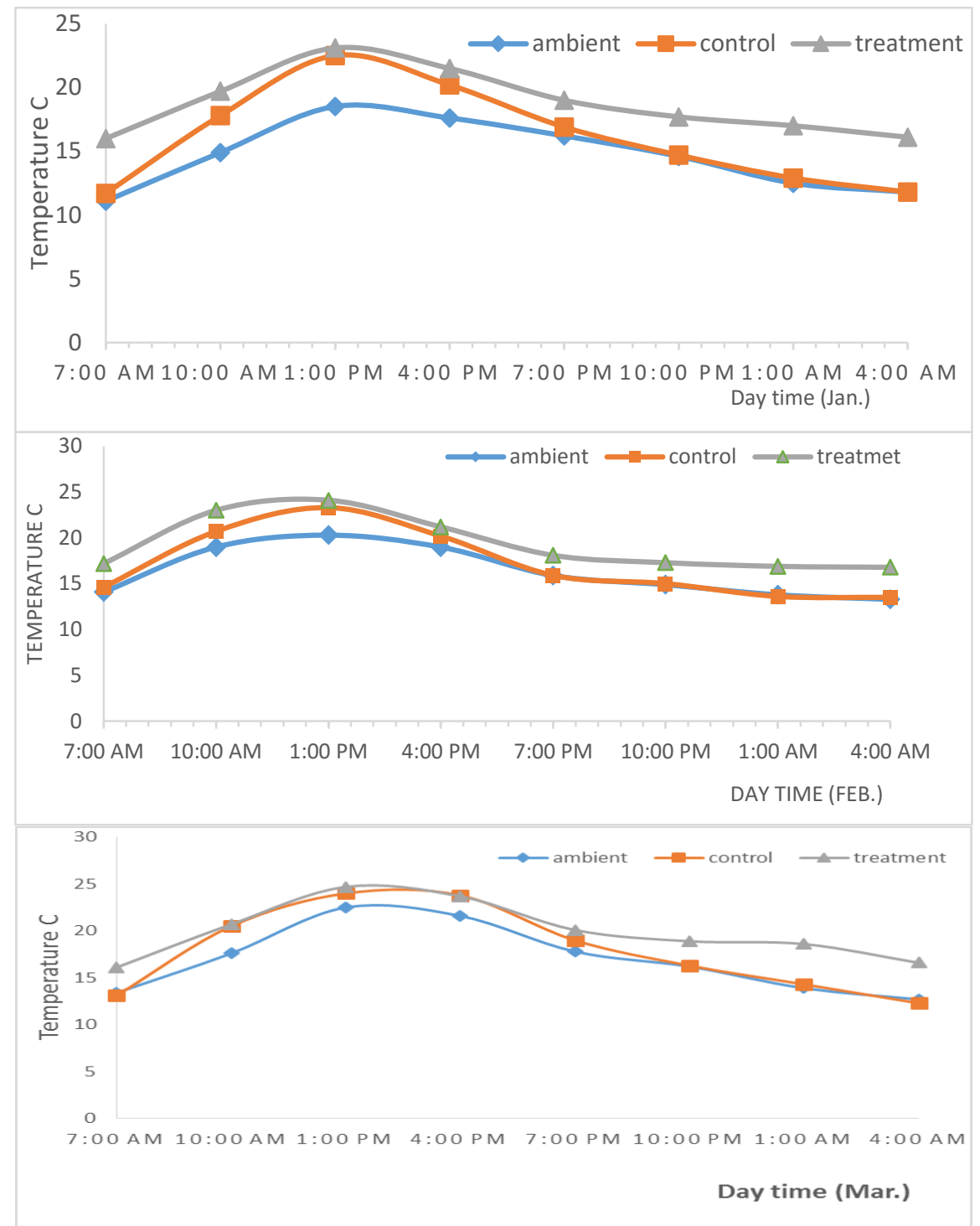

Fig. (2): The average air temperatures outside and inside the treatment and control greenhouses vs. time during (January to March). 
The temperatures of the treatment greenhouse was higher than the control one, and of course the ambient temperature was the lowest. Also, at night and up to 4.0 AM the temperatures of the control greenhouse and the ambient were almost the same.

2- Relative humidity

Fig; (3) shows the hourly relative humidity variation of the greenhouse. It is clear that the relative humidity inside the greenhouses gradually decreased with time it reached to the minimum

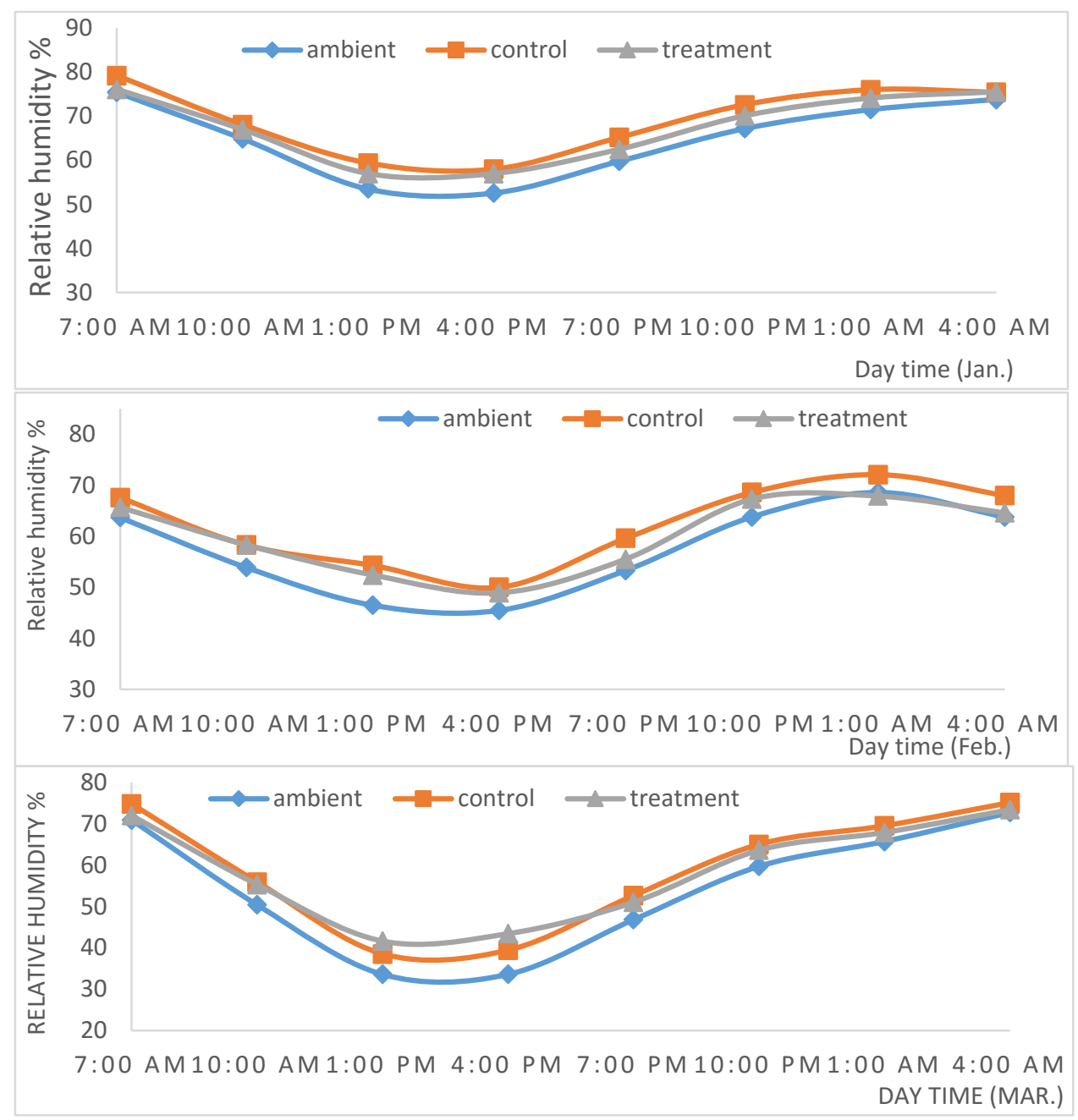

Fig. (3): Average air relative humidity outside and inside the treatment and control greenhouses vs. time during (January to March). 
value at about 3 PM for all measurements then increased up to 4 AM. These results could be attributed to the fact that the level of the inside relative humidity is accompanied by the level of temperatures inside the greenhouses. The results has also show that the relative humidity of the control greenhouse is higher than the treatment one and there is slight increase in the relative humidity of the ambient comparing with the relative humidity of the control greenhouse.

\section{3- Firmness}

Figures (4), (5) and (6) represent the average firmness value of tomato fruits of the treatment and control greenhouses. It was $1.85 \mathrm{~N} / \mathrm{mm}$ and 1.0 $\mathrm{N} / \mathrm{mm}$, respectively; this means that the firmness value of tomato fruits of the treatment greenhouse was greater by $85 \%$.

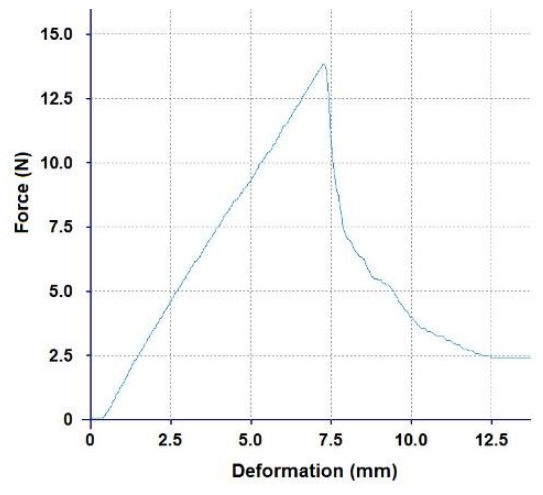

Fig. (4) Tomato's force-deformation behavior (treatment greenhouse)

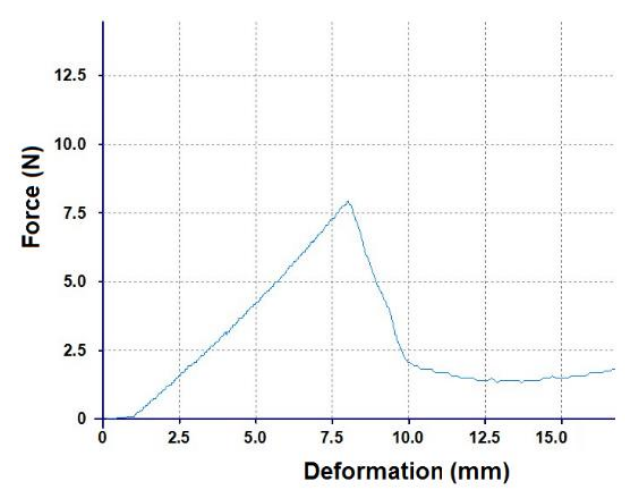

Fig. (5) Tomato's force-deformation behavior (control greenhouse)

4- Toughness

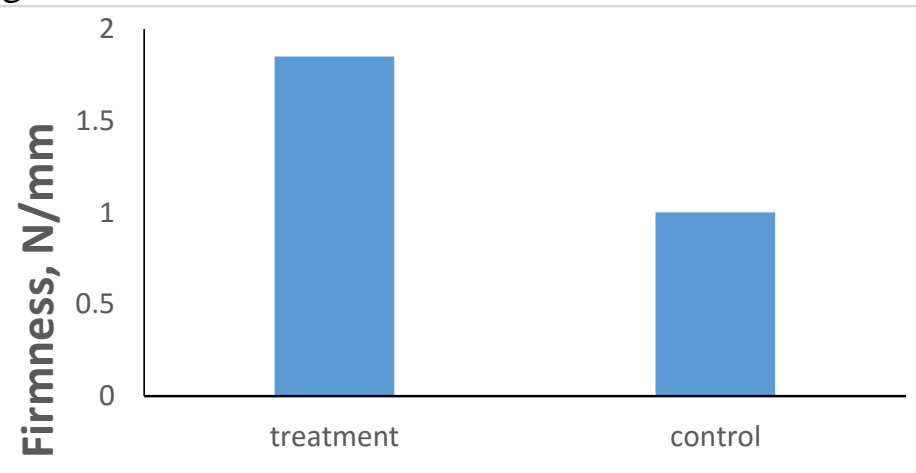

Fig. (6): Values of firmness of tomato fruits in treatment and control greenhouses. 
Figs (4),(5) and (7) show the average toughness value of tomato fruits of the treatment and control greenhouses. It was 45.5 N.mm and 28 N.mm, respectively. This means that the percentage of increasing of toughness of tomato fruits was about $62.5 \%$.

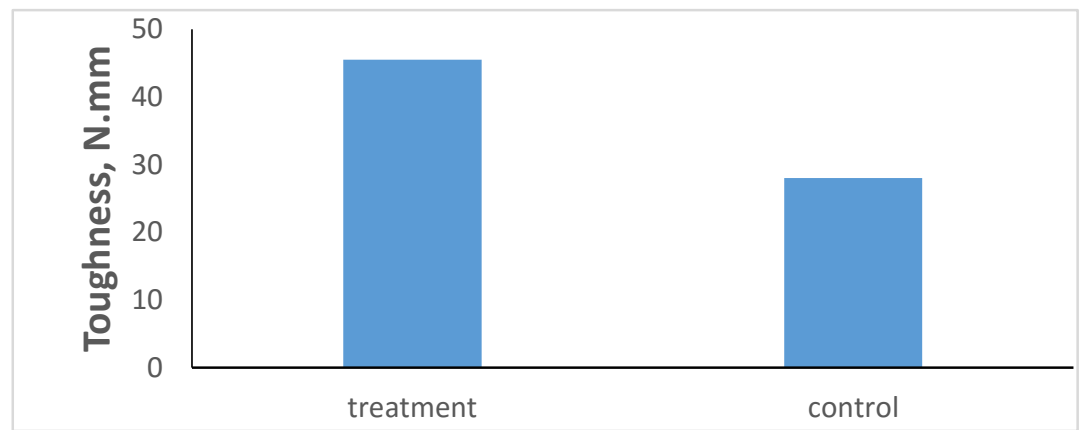

Fig. (7): Value of toughness of tomato fruits of the treatment and control greenhouses.

5- Heat losses through the greenhouse

Fig. (8) showed the results of the mean components $\left(\mathrm{Q}_{\mathrm{v}}, \mathrm{Q}_{\mathrm{c}}\right)$ and $\mathrm{Q}_{\mathrm{t} t a \mathrm{l}}$ of the greenhouse energy loses (treatment greenhouse) during the daytime of February 27, 2012. It can be noticed that, energy lost via ventilation increasing gradually from 7AM to $10 \mathrm{AM}$ and decreasing before $1 \mathrm{PM}$ to

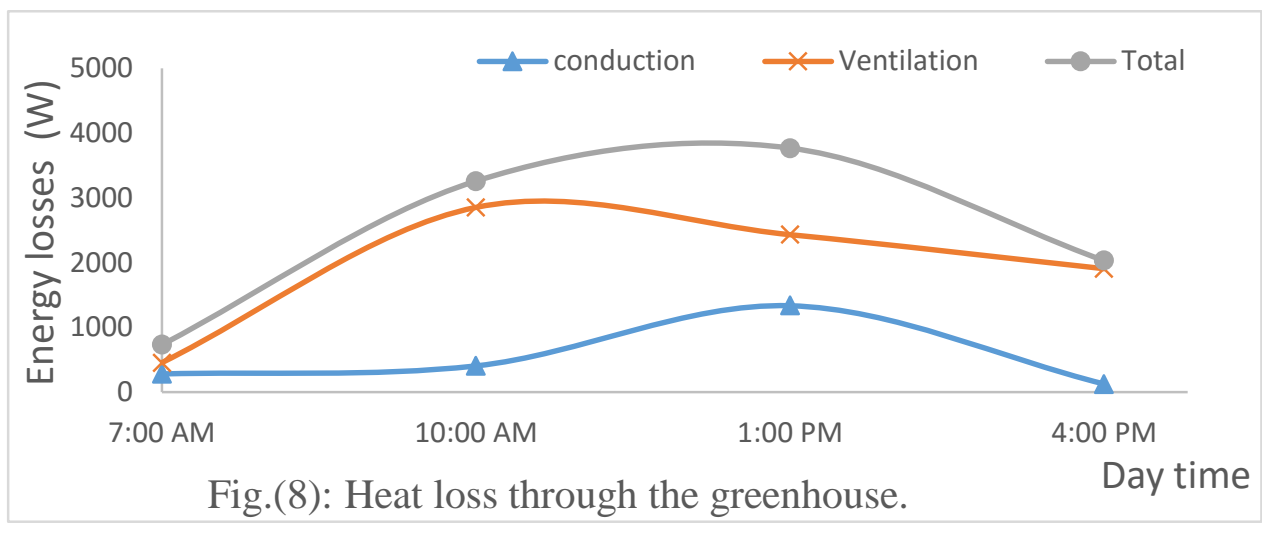

$4 \mathrm{PM}$ but the heat flow through the polyethylene was approximately stable from $7 \mathrm{AM}$ to $10 \mathrm{AM}$ and began to increase gradually after $10 \mathrm{AM}$ to $1 \mathrm{PM}$, then decreasing after $1 \mathrm{PM}$ to $4 \mathrm{PM}$. Also, it be noticed that the greatest total losses of the energy from the greenhouses were at about 1.0 PM The reason of that is the air temperature difference between outside and inside greenhouse was maximum. 
6- Effect of heat and ventilation on plant growth

Fis (9), (10), (11) and (12) show the effect of heat and mechanical ventilation on the average number of leaves, plant height, stem diameter and tomato production per plant during winter season of 2012. The obtained data show significant increase in all the above parameters in case of the treatment greenhouse as compared with the control greenhouse. Such increases were $28.98 \%, 22.21 \%, 28.75 \%$ and $57.69 \%$, respectively, at the end of the growth season.

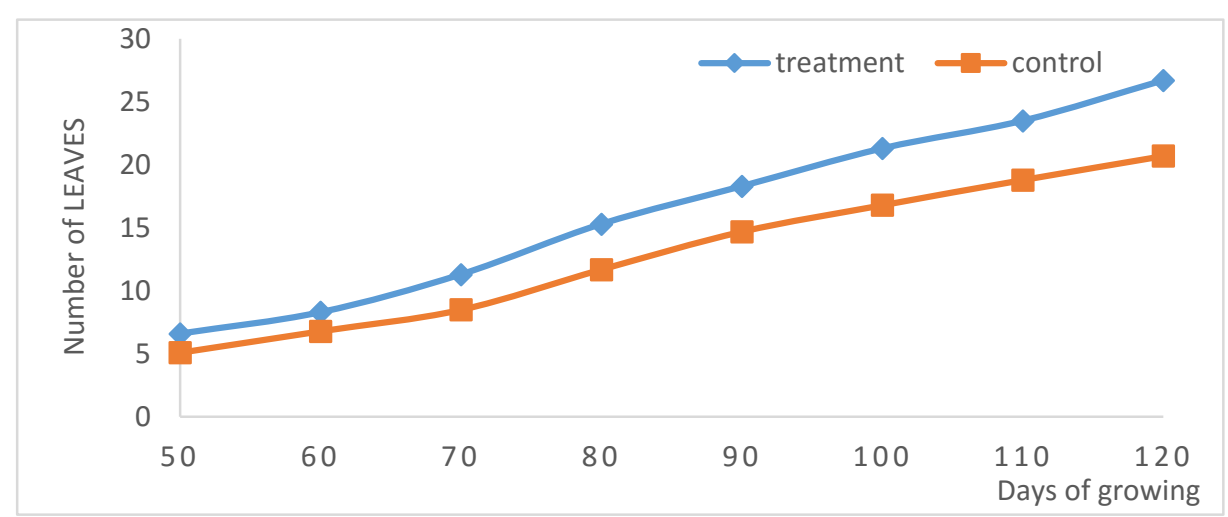

Fig. (9): The average variation in leaves number of the treatment and control greenhouses through growing season.

These increases may be due to control the interior climate (heat and $\mathrm{RH}$ ) for plant growth under environmentally appropriate conditions, which help for (a) increasing the rate of nutrient absorption due to maintaining the optimum growth temperature; (b) forming a large number of leaves, which are necessary for photosynthesis process; and (c) increasing diameter and height of stem and consequently increasing the tomato production.

\section{CONCLUSION}

An experimental polyethylene greenhouse was constructed and equipped with heating and mechanical ventilation system to investigate the effect of air temperature and relative humidity on plant growth of early production of tomato crop during winter season of (2012) the designed system was supplied with environmental instruments to control the interior climate for high-yield conditions and it was compared with a traditional greenhouse the results showed an increase in number of leaves, stem height, stem diameter, tomato production, average value of firmness, and average value of toughness by $28.98 \%, 22.21 \%, 28.75 \% 57.69 \%, 85 \%$, and $62.5 \%$, respectively. 


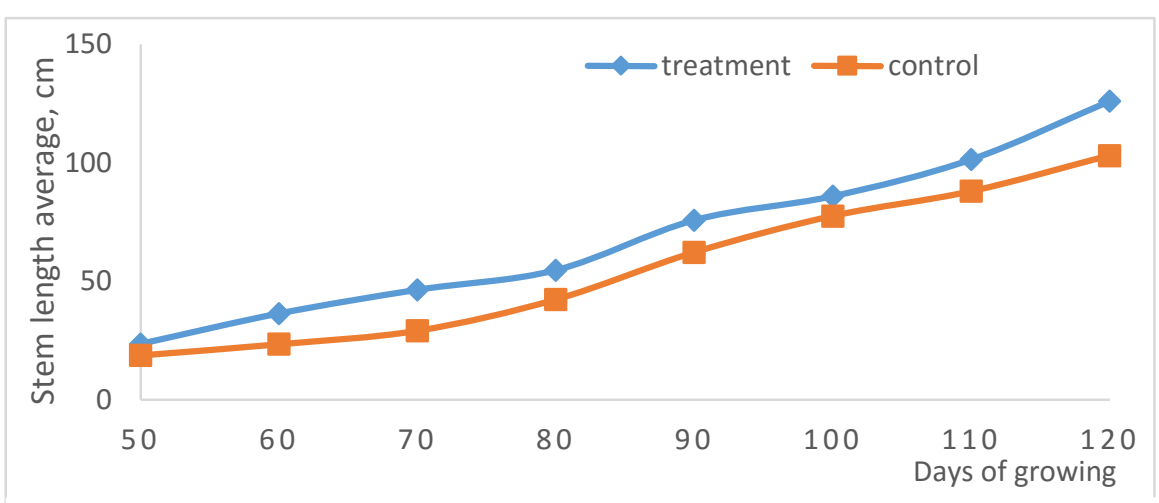

Fig. (10): The average variation in stem length of the treatment and control greenhouses through growing season.

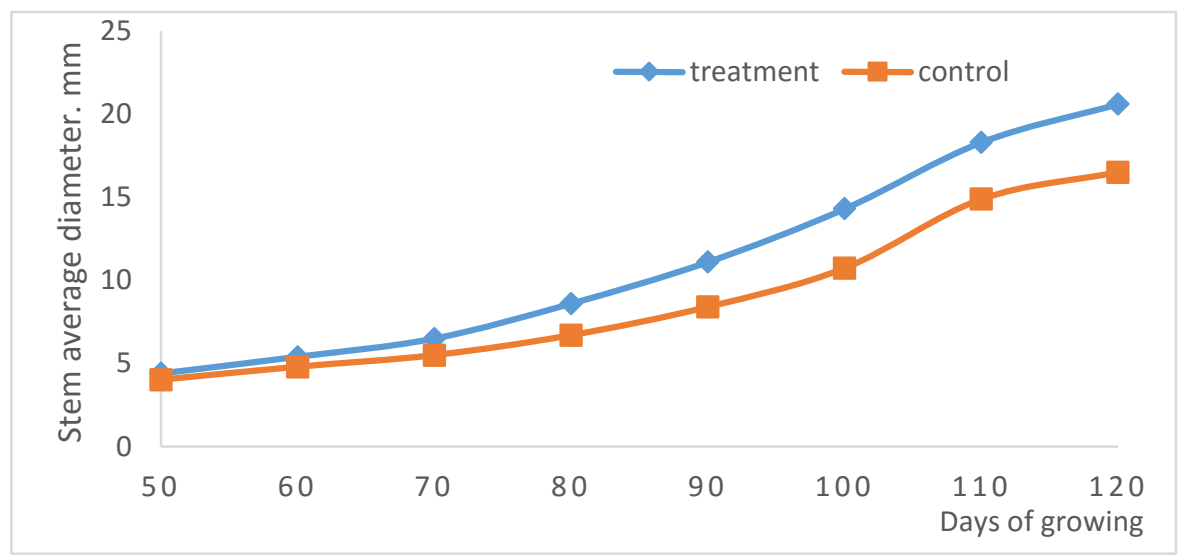

Fig.(11): The average variation in the stem diameter of the treatment and control greenhouses through growing season.

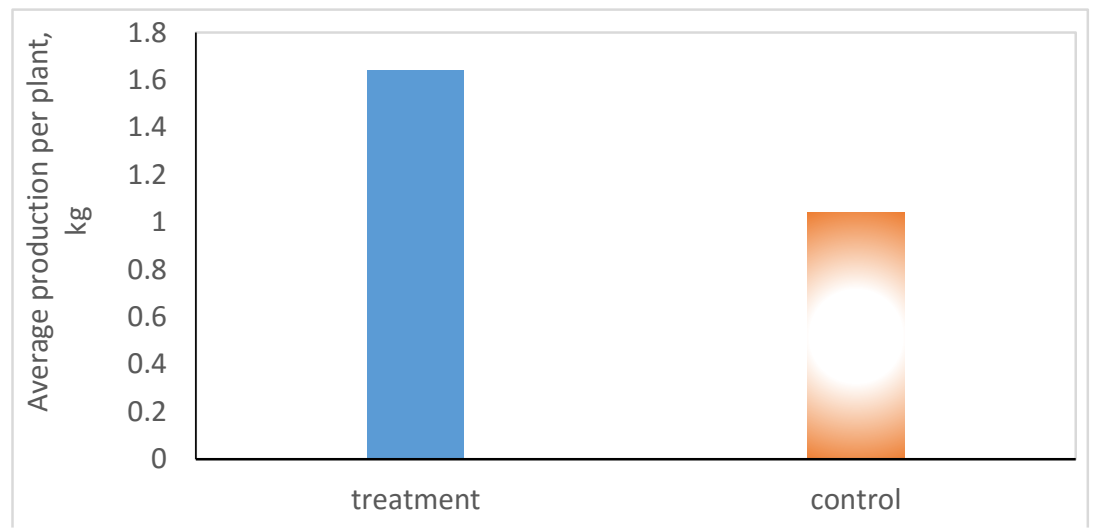

Fig. (12): The average production per plant of the treatment and control greenhouses at the end of growing season. 


\section{RECOMMENDATION}

As a future work, it is recommended to use a solar heating system for substitution of stored solar energy for a significant portion of the electrical energy (that was used in this study, to heat the treatment greenhouse) in order to reduce the electrical consumption and save production cost.

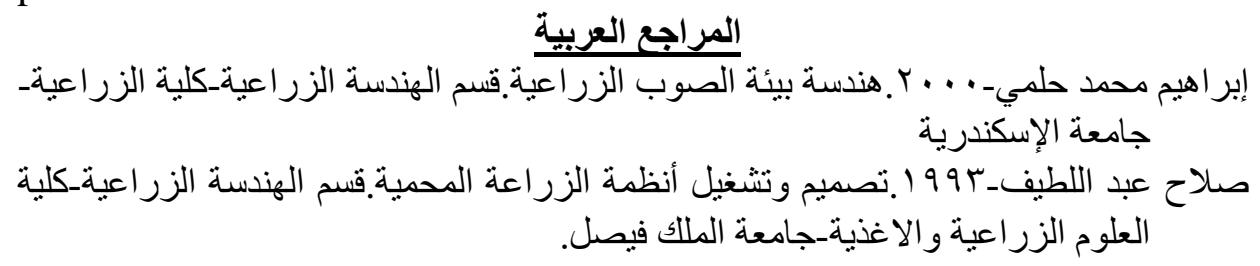

\section{REFERENCES}

Aldrish,A.R.and Bartok.W.J.(1994).greenhouse engineering. NRASE-33$3^{\text {rd }}$ edition

BATU, A. (1998). Some factors affecting on determination and measurement of tomato firmness. Tr. J. of agriculture and forestry 22(1998) 411-418.

Buffington, D.E.; Bucklin, D.A.; Henley, R.W. and Mc Connell, D.B. (2002). Fans for greenhouses, institute of food and agriculture science, university of Florida AE-12

Gao,Z.(2012).Dehumidification of greenhouses in cold regions. Thesis, degree of, Sc, Uni. of Saskatchewan.

Jackman, R. L., A. G. Marangoni and Stanely, D. W. (1990). Measurement of tomato fruit firmness, Hort Science. 25(7):781783.

Rajabipour,A.(1995).Effects of $\mathrm{Ca}, \mathrm{K}$ and water table depth on tomato mechanical properties; $\mathrm{PhD}$ thesis, McGill Univ. MacDonald campus.

Shafiee, s; Motlag,A.M; Didar,R.A., and Minaee,s.(2008). Investigation the effect of skin on mechanical behavior of apple, journal of food technology 6(2):86-91, 2008.ISSN:1684-8426.

Sirisomboon,P. ; Tanaka,M. ; Kojima,T. and William,P. (2012). Nondestructive estimation of maturity and textural properties on tomato 'momotaro' by near infrared spectroscopy. Journal of Food Engineering 112 (2012) 218-226.

Li, Z.; Li,P.; and Liu, J. (2011), Physical and mechanical properties of tomato fruits as related to robot's harvesting. Journal of food engineering 103 (2011) 170- 178. 


\section{الملخص العربي \\ نظام التحكم في التدفئة والتهوية للبيت المحمي

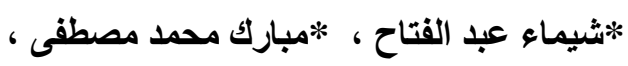

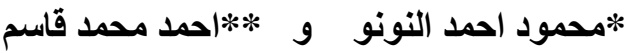

تستخدم الصوب الزراعية في مصر على نطاق واسع ومنز ايد لإنتاج الخضر اوات والفو اكه الخها

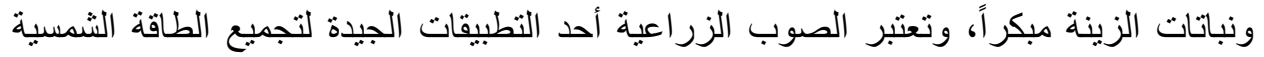

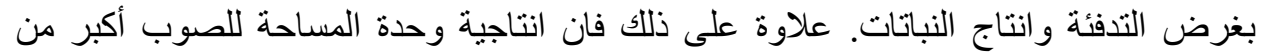

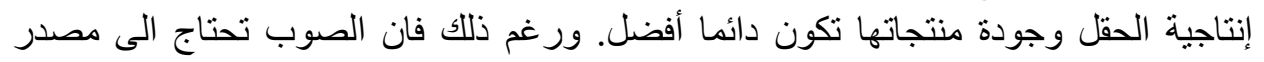
حرارة اضافي في فصل الثتاء خاصة اثناء الليل وخلال الفترات التي تكون فيها السماء ملبدة التهاء بالغيوم لإمداد النباتات باحتياجاتها الحرارية ولذا فمن الضروري التحكم في درجة حرارة

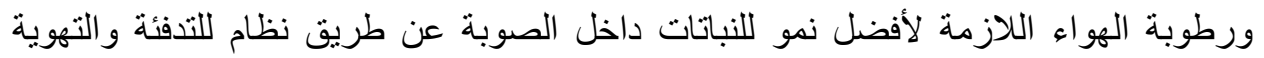

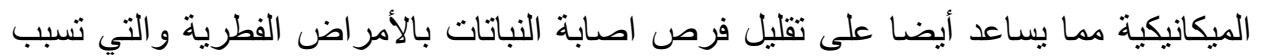
خسائر فادحة للمز ارع و التي يصعب داعب مكافحتها عن طريق المبيدات. إن التحكم في الظروف المناخية ذو اهمية كبيرة للإنتاج داخل الصوب لتحفيق اعلى اعلى انتاجية بأقل تكلفة وبأفضل جودة والتي يحتاجها السوق و المستهلك وتعد درجة الحرارة وكذلك الرطوبة من التمبن

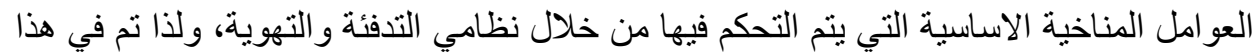
البحث تطوير، انشاء و اختبار صوبة تجريبية مزودة بنظام للتحكم في التدفئة و التهوية لتوفير

الظروف المثلي لبيئة نمو نبات الطماطم اثناء فصل الثتاء من خلال: -

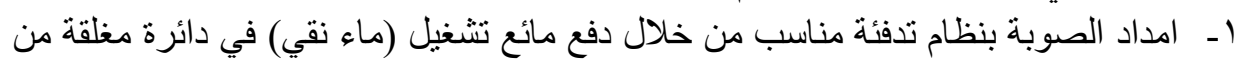

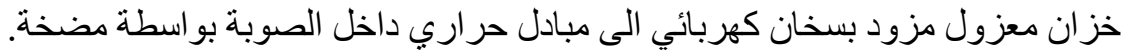

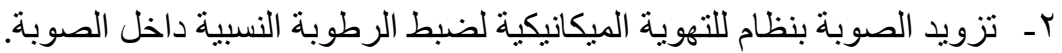

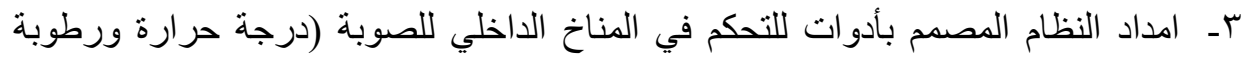

نسبية) عن طريث ثرموستات وحساس للرطوبة لتوفير الظروف البيئية المناسبة للنبات.

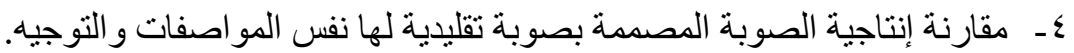

ويمكن تلخيص النتائج فيما يلي: زيادة عدد أوراق النباتات، طول النبات، قطر النبات، الانتاجية

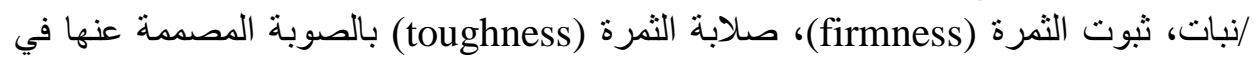

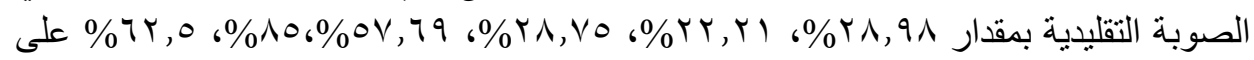
التو الي. نوصى باستخدام نظام تسخين شمسي لإحلال الطاقة الشمسية المخزنة كجزء بـ بـلا من

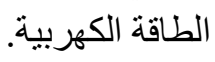

*قمم الـندسة الزراعية ـكليه الزراعة_جامعه عين شمس. * * معهد بحوث الهندسة الزراعية. 